\title{
Typhoid fever in the Russian Federation
}

\author{
P.G. Aparin, S.M. Golovanev, Y.P. Solodovnikov
}

\begin{abstract}
Abstrak
Tingkat morbiditas demam tifoid di Federasi Rusia selama tahun 1991-96 berkisar antara 0,2-0,6 kasus per 100.000. Ini merupakan suatu angka yang lebih rendah dibandingkan dengan data dari USSR selama tahun 1985-90, yang berjumlah 8-10 kasus per 100.000. Hal ini disebabkan karena jumlah kasus yang lebih banyak di negara-negara Asia Tengah yang dahulunya menjadi bagian dari USSR. Meskipun demikian, juga dilaporkan terjadinya peningkatan jumlah kasus di Federasi Rusia, misalnya di Dagestan, KarachaevoCherkessia dan Krasnodar. Untuk usaha memonitor infeksi juga dilakukan pencatatan kasus pengidap (carrier) dari demam tifoid. Keadaan yang paling memprihatinkan pada negara-negara ex-USSR dijumpai di Tajikistan. Pada daerah ini masih dijumpai kelanjutan dari kejadian luar biasa demam tifoid sejak tahun 1996, dengan peningkatan yang tajam dari morbiditas dan jumlah kasus yang dilaporkan sejak Januari 1997. Jumlah kasus telah melampaui angka 100.000 (laporan Dinas Epidemiologi) sedangkan menurut perkiraan WHO angka ini mencapai 50-60.000 kasus. Termasuk lokasi yang terjangkit kejadian luar biasa dari demam tifoid ini adalah ibukota Dushanbe dan bagian sentral Kuliab. Sumber dari penyebaran diperkirakan adalah air yang tercemar. Sedangkan faktor lainnya adalah fasilitas sanitasi dan higiena yang tidak memadai. Di Dushanbe telah dipersiapkan delapan rumah sakit untuk menangani kasus-kasus demam tifoid. Angka kematian dilaporkan sebesar 10\% bila tidak diberikan pengobatan antibiotika dan $1 \%$ pada kasus-kasus yang mendapat pengobatan.
\end{abstract}

\begin{abstract}
Typhoid fever morbility level for Russian Federation in 1991-96 varied from 0.2 to 0.6 cases per 100,000. This is rather low figures in comparison with data obtained in 1985-90 for USSR which consist of 8-10 cases per 100,000. Main impact in typhoid fever morbidity in USSR may be referred to Middle Asia ex-USSR republics which are independent states now. In some regions of Russia: Dagestan, Karachaevo-Cherkessia, Krasnodar region registered increased level of typhoid fever cases. Typhoid fever bacteria carriers are also registered too during monitoring of infection. The most dangerous situation on ex-USSR territory is registered in Tajikistan. Typhoid fever outbreak from the middle of 1996 is still spreading. Serious increase in morbidity with an alarming number of cases has faced since January 1997. Total number of cases reach from 50-60,000 (WHO estimation) to 100,000 (Epid Service estimation). Large towns capital Dushanbe, regional center Kuliab are affected by typhoid fever outbreak. The source of contamination is water. Secondary transmission due to poor sanitary facilities and hygiene is reported. Eight typhoid fever hospitals are organized in Dushanbe now. Fatality rate is $1 \%$ with treatment and up to $10 \%$ without appropriate antibiotic treatment.
\end{abstract}

\section{Typhoid fever incidence and its trends}

Typhoid fever still remains an endemic infectious disease in the Russian Federation (RF). In 1991-1997 (Table 1) in RF annually were registered from 330 to 830 cases of typhoid fever, morbidity rates varied between 0.2-0.6 per 100,000 population. On the background of some decrease and stability of the morbidity rates in 1995 and 1996 nevertheless notable increase of the activity of the epidemic process took place in 1997. During the last 9 months of 1997 (January-September) more cases of typhoid fever (357) were registered than in each of the two previous years. These statistical data, including also an abrupt rise of the morbidity rate in 1993 (830 cases with morbidity rate equal to 0.6 per 100,000 popula-

Institute of Immunology, Moscow, Russia tion), by themselves reflect nonstability of the epidemic situation as to typhoid fever in RF with high probability of its deterioration in the nearest future.

\section{Case-fatality rate}

In RF annually we registered a few fatal cases due to typhoid fever (Table 2). In 1992-1996 the number varied from 2 in 1996 (lowest incidence rate) to 9 in 1993 (highest incidence rate).

Table 1. Typhoid fever morbidity rates in the Russian Federation in 1991-1997

\begin{tabular}{lccccccc}
\hline Year & 1991 & 1992 & 1993 & 1994 & 1995 & 1996 & $1997^{*}$ \\
\hline $\begin{array}{l}\text { Number of } \\
\text { cases }\end{array}$ & 403 & 455 & 830 & 450 & 330 & 330 & 357 \\
$\begin{array}{l}\text { Per 100,000 } \\
\text { population }\end{array}$ & 0,3 & 0,3 & 0,6 & 0,3 & 0,2 & 0,2 & - \\
\hline
\end{tabular}

* Data relate only to 9 months of the year. 
Table 2. Number of deaths and case-fatality rate due to typhoid fever in the Russian Federation in 1992-1996*

\begin{tabular}{lccccc}
\hline & 1992 & 1993 & 1994 & 1995 & 1996 \\
\hline Number of deaths & 5 & 9 & 8 & 5 & 2 \\
Case-fatality (\%) & 1,1 & 1,1 & 1,8 & 1,1 & 0,6 \\
\hline
\end{tabular}

* Data in 1997 is not available

Case-fatality rate on the whole is low and varies from 0.6 to $1.8 \%$. Tendency to decrease of case-fatality rate in the recent years reflects still high efficacy of the methods used for the treatment of typhoid fever. Objectively these statistical data reflect till now available sensitivity of Salmonella typhi, the infection agent causing typhoid fever, to levomycetine (chloramphenicol) - the drug of choice widely used for treatment of the disease. Appearance of strains of $S$. typhi which were resistant to this antibiotic of choice in some foreign countries (Mexico etc), caused abrupt increase of case-fatality rate number of deaths (percentage among patient with typhoid fever) up to the level, which had been typical for this infection in the preantibiotic era ( $10 \%$ and more). Perspective of the development among $S$. typhi strains in RF the antibiotic resistance, particularly to chloramphenicol, is quite real in the nearest 5-10 years with all unfavorable clinical consequences of the disease (uncontrolled) rise of case-fatality rate.

In the resent years cases of death due to typhoid fever in RF, as a rule were connected with late diagnosis of typhoid fever, which lead to the occurrence of such severe complications as intestinal haemorrhage and intestinal perforation.

\section{Paratyphoid fevers A, B, C}

In comparison with typhoid fever, paratyphoid fevers A,B,C (mostly paratyphoid fever B) spread in RF to much less extent. Epidemic process of these infections is being realized mainly only on a sporadic level. During 1991-1997 (Table 3) in RF annually registered cases of paratyphoid fevers were from 40 to 93 .

Table 3. Paratyphoid fever A,B,C morbidity rates in the Russian Federation in 1991-1997

\begin{tabular}{lccccccc}
\hline & 1991 & 1992 & 1993 & 1994 & 1995 & 1996 & 1997 \\
\hline $\begin{array}{l}\text { Number of } \\
\text { cases }\end{array}$ & 77 & 93 & 64 & 63 & 58 & 37 & $42(?)$ \\
$\begin{array}{l}\text { Per } 100,000 \\
\text { population }\end{array}$ & 0,05 & 0,06 & 0,04 & 0,04 & 0,04 & 0,03 & $?$ \\
\hline
\end{tabular}

Since 1992 up to 1996 a trend to the decrease of incidence of these infections could be seen. But in 1997 (identically with typhoid fever), taking into consideration the incidence level of paratyphoid fevers during first 9 months of the year, is expected some rise of the morbidity rate in comparison with the previous year (1996). Nevertheless the forecast concerning paratyphoid fevers $A, B, C$ (not typhoid fever) is quite favorable as to the nearest and remote future - nowadays in the RF these infections have lost their capacity for epidemic distribution as a result, particularly, of much less expressed virulent properties of S.paratyphi $\mathrm{A}, \mathrm{B}, \mathrm{C}$ unlike $S$. typhi. Morbidity rates during the period of time under consideration (1991-1996) decreased from 0.06 per 100,000 population in 1992 down to 0.03 in 1996 (twofold decrease). On the background of a rather limited spread of paratyphoid fevers in the RF, still isolated cases of death due to them were registered: in $1992-2$ cases of death, in $1994-1$ and in 1996-1. In 1993 and 1995 there were no cases of death in RF due to these infections. The cases of death of patients with paratyphoid fevers $\mathrm{A}, \mathrm{B}, \mathrm{C}$ the same as by typhoid fever: severe complications with intestinal haemorrhage and perforation.

\section{Geography of typhoid fever}

Typhoid fever is an unevenly distributed infection through various administrative territories of the RF. Besides the territories with very low typhoid fever incidence (single case or no case at all), there are some territories, where this infection is constantly wide spread - incidence essentially exceeds average levels in the Federation. Although the average typhoid fever morbidity rate in RF in 1996 was equal only to 0.22 per 100,000 population, much higher levels of the morbidity were registered in Smolenskaya (1.46) and Astrahanskaya (0.78) provinces, in the Republic of Dagestan (1.34), Karachaevo-Cherkessia Republic (6.00), Chechen Republic (0.80). Hanty-Mansiyski administrative district $(0.97)$ and in some other territories.

A constant presence among population of some very huge reservoir of infection - chronic typhoid carrierspermanently creates very dangerous situation from epidemic point of view: sporadic cases, outbreaks and epidemics of typhoid fever can occur in any territory as a result of violation of sanitary rates concerning water supply and excreta disposal, provision of the population with safe food stuffs. Most unstable situation in that respect is maintained in the territories with unsatisfactory water supply of population (bad quality and shortage of water). New epidemic factor 
for risk of typhoid fever appeared in the recent years - flourishing unlegal street trade with various foodstuffs and also a new system of wholesale trade, attracting huge numbers of people. In Moscow in 1997 we have already got 13 cases of typhoid fever among foreign tradesmen from Aserbaidsan in one of these numerous wholesale trade markets. It is a new and serious epidemic threat.

\section{Typhoid fever among urban and rural population}

Concerning the spread of typhoid fever among urban and rural population in RF (Table 4), it is nessesary to pay attention to the fact, that although there is some similar trend to decrease of the infection in both populations, nevertheless annual incidence during 1991-1996 among rural population is a little bit higher compared to urban population (difference is not considerable and equal only to 0.1 per 100,000 population). At the same time number of cases of typhoid fever and their proportion (\%) among urban population, especially at the beginning of considered period, was notably higher (70.0-78.0\%). In 1996 on the background of some decrease of the number of cases of typhoid fever among urban population in comparison with 1995 (from 230 cases to 201), the number of cases among rural population even increased (from 100 cases to 129) and as a result their proportion (\%) increased to $39.1 \%$. Real epidemiological meaning of the phenomenon has to be further investigated.

Table 4. Typhoid fever morbidity rates among urban and rural population in the Russian Federation in 1991-1996

\begin{tabular}{lccccccc}
\hline \multicolumn{1}{c}{1991} & 1992 & 1993 & 1994 & 1995 & 1996 \\
\hline $\begin{array}{l}\text { Urban } \\
\text { population }\end{array}$ & $\begin{array}{c}\text { Number } \\
\text { of cases } \\
\%\end{array}$ & 292 & 355 & 581 & 276 & 230 & 201 \\
& 72.5 & 78.0 & 70.0 & 61.4 & 69.7 & 60.9 \\
$\begin{array}{c}\text { Per 100,000 } \\
\text { population }\end{array}$ & 0.3 & 0.3 & 0.5 & 0.3 & 0.2 & 0.2 \\
\hline $\begin{array}{l}\text { Rural } \\
\text { population }\end{array}$ & $\begin{array}{c}\text { Number } \\
\text { of cases } \\
\%\end{array}$ & 111 & 100 & 249 & 174 & 100 & 129 \\
& 27.5 & 22.0 & 30.0 & 38.6 & 30.3 & 39.1 \\
& $\begin{array}{c}\text { Per 100,000 } \\
\text { population }\end{array}$ & 0.3 & 0.3 & 0.6 & 0.4 & 0.3 & 0.3 \\
\hline
\end{tabular}

\section{Paratyphoid fevers A,B,C among urban and rural population}

Paratyphoid fevers A,B,C are distributed unevenly among urban and rural population in RF. Among urban population incidence in 1991-1996 varied in the range 0.03-0.07 per 100,000 population, among rural population - between 0.01-0.04. Almost constantly levels of incidence of paratyphoid fevers A,B,C stay low and do not change essentially. Main part of cases (73.0-93.1\%) occurs among urban population. Most probably this trend will be maintained in the near future on the background of further decrease of paratyphoid fevers $A, B, C$ in $R F$ on the whole.

Table 5. Paratyphoid fevers A,B,C morbidity rates among urban and rural population in the Russian Federation in 19911996

\begin{tabular}{lcccccccc}
\hline & 1991 & 1992 & 1993 & 1994 & 1995 & 1996 \\
\hline $\begin{array}{l}\text { Urban } \\
\text { population }\end{array}$ & $\begin{array}{c}\text { Number } \\
\text { of cases }\end{array}$ & 62 & 78 & 52 & 46 & 54 & 27 \\
& $\%$ & 80.5 & 83.9 & 81.3 & 73.0 & 93.1 & 73.0 \\
& $\begin{array}{c}\text { Per 100,000 } \\
\text { population }\end{array}$ & 0.06 & 0.07 & 0.05 & 0.04 & 0.05 & 0.03 \\
\hline $\begin{array}{l}\text { Rural } \\
\text { population }\end{array}$ & $\begin{array}{c}\text { Number } \\
\text { of cases }\end{array}$ & 15 & 15 & 12 & 17 & 4 & 10 \\
& $\%$ & 19.5 & 16.1 & 18.7 & 27.0 & 6.9 & 27.0 \\
& $\begin{array}{c}\text { Per 100,000 } \\
\text { population }\end{array}$ & 0.04 & 0.04 & 0.03 & 0.04 & 0.01 & 0.03 \\
\hline
\end{tabular}

Age incidence of typhoid fever and paratyphoid fevers $\mathbf{A}, \mathbf{B}, \mathbf{C}$

Typhoid fever and paratyphoid fevers A,B,C are distributed rather evenly among children's and adult population in RF. During 1991-1996 morbidity rate among children stayed practically at one and the same level and was almost constantly equal to 0.2 per 100,000 of children at the age under 15 years. The year of 1993 happened to be an exception, when on the background of the increase of typhoid fever incidence on the whole, took place also 3.5-fold increase of the morbidity rate (up to 0.7 per 100,000 children) among the children's population under 15 . Nevertheless main part of the typhoid fever cases has been constantly registered among adult population, which represents by itself some contingent of higher epidemic risk as concerns typhoid fever infection.

\section{Age incidence of paratyphoid fevers $A, B, C$}

Although paratyphoid fevers A,B,C are much less spread in RF as compared with typhoid fever, their age distribution (Table 7) nevertheless is quite similar to that disease; most of cases $(73.0-89.3 \%)$ are also registered among adult population. 
Table 6. Typhoid fever morbidity rates of children's and adult population in the Russian Federation in 1991-1996

\begin{tabular}{|c|c|c|c|c|c|c|c|}
\hline & & 1991 & 1992 & 1993 & 1994 & 1995 & 1996 \\
\hline \multirow{4}{*}{$\begin{array}{l}\text { Children } \\
\text { population } \\
\text { (under } 15 \\
\text { years }\end{array}$} & $\begin{array}{l}\text { Number } \\
\text { of cases }\end{array}$ & & & & & & \\
\hline & & 69 & 73 & 228 & 75 & 60 & 66 \\
\hline & $\%$ & 17.1 & 16.0 & 17.5 & 16.7 & 18.2 & 20.0 \\
\hline & $\begin{array}{l}\text { Per } 100,000 \\
\text { f age specific } \\
\text { population }\end{array}$ & 0.2 & 0.2 & 0.7 & 0.2 & 0.2 & 0.2 \\
\hline \multirow[t]{3}{*}{$\begin{array}{l}\text { Adult } \\
\text { population }\end{array}$} & $\begin{array}{l}\text { Number } \\
\text { of cases }\end{array}$ & 334 & 382 & 602 & 375 & 270 & 264 \\
\hline & $\%$ & 82.9 & 84.0 & 72.5 & 83.3 & 81.8 & 80.0 \\
\hline & $\begin{array}{l}\text { Per } 100,000 \\
\text { f age specific } \\
\text { population }\end{array}$ & 0.3 & 0.3 & 0.5 & 0.3 & 0.2 & 0.2 \\
\hline
\end{tabular}

Table 7. Paratyphoid fevers A,B,C morbidity rates among children's and adult population in the Russian Federation in 1991-1996.

\begin{tabular}{|c|c|c|c|c|c|c|c|}
\hline & & 1991 & 1992 & 1993 & 1994 & 1995 & 1996 \\
\hline \multirow{4}{*}{$\begin{array}{l}\text { Children } \\
\text { population } \\
\text { (under } 15 \\
\text { years }\end{array}$} & $\begin{array}{l}\text { Number } \\
\text { of cases }\end{array}$ & & & & & & \\
\hline & & 16 & 10 & 14 & 16 & 8 & 10 \\
\hline & $\%$ & 20.8 & 10.7 & 21.9 & 25.4 & 13.8 & 27.0 \\
\hline & $\begin{array}{l}\text { age specific } \\
\text { age sopulation }\end{array}$ & 0.04 & 0.02 & 0.04 & 0.05 & 0.03 & 0.03 \\
\hline \multirow[t]{3}{*}{$\begin{array}{l}\text { Adult } \\
\text { population }\end{array}$} & $\begin{array}{l}\text { Number } \\
\text { of cases }\end{array}$ & 61 & 83 & 50 & 47 & 57 & 27 \\
\hline & $\%$ & 79.2 & 89.3 & 78.1 & 74.6 & 86.2 & 73.0 \\
\hline & $\begin{array}{l}\text { er } 100,000 \text { of } \\
\text { age specific } \\
\text { population }\end{array}$ & 0.05 & 0.07 & 0.04 & 0.04 & 0.04 & 0.02 \\
\hline
\end{tabular}

On the whole both typhoid fever and paratyphoid fevers $\mathrm{A}, \mathrm{B}, \mathrm{C}$ are characterized by their predominating distribution among the most socially active age groups of the adult population (especially at the age of 20-29 and 30-39 years), which are mostly engaged with interregional and international business, trade, "shuttle" activities and also with tourist and other travels to the nearest and far countries abroad.

Among children under 15 , most cases (50\% and more) occur among school children, the socially most active part of children's population.

\section{Seasonable distribution}

Uneven seasonal distribution of typhoid fever and paratyphoid fevers $A, B, C$ in $R F$ in the recent year are still expressed rather clear, especially in the years, when large epidemic outbreaks occur.

In 1995-1997 cases of typhoid fever in RF were registered during all months of each year without any exclusions, reflecting a very deep epidemic rooting of the infection in population, but relative frequency of occurrence of these cases in separate months and seasons of the year was greatly different (Table 8)

Typhoid fever, remaining an all year round infection, mostly is a disease of the second half of the year, when were registered from $58,8 \%$ (1996) to $68.8 \%$ (1995) of all cases, which occur during those years. But it is necessary to underline, that the rise of morbidity starts already in the second quarter of the year, when its rates double compared with the rates in the first quarter of the year: in 1995 from $10,3 \%$ up to $21,7 \%$ and in 1996 from 13,4 up to 27,8 correspondingly. In other words, epidemic process of typhoid fever is very active all the year round with some decrease of its activity only in the first quarter of the year.

Distribution of typhoid fever increases abruptly in the not season of the year, especially on the background of water shortage and poorly organized excreta disposal in the territories, where so called chronic water-

Table 8. Seasonal distribution of typhoid fever cases in the Russian Federation in 1995-1997

\begin{tabular}{|c|c|c|c|c|c|c|c|c|c|c|c|c|c|c|}
\hline & & $\mathrm{I}$ & II & III & IV & V & VI & VII & VIII & IX & $\mathrm{X}$ & $\mathrm{XI}$ & XII & Total \\
\hline \multirow[t]{2}{*}{1995} & Number of cases & 11 & 16 & 18 & 19 & 31 & 23 & 26 & 22 & 17 & 57 & 35 & 71 & 33 \\
\hline & $\%$ & 3.3 & 1.7 & 5.3 & 5.5 & 9.2 & 7.0 & 7.6 & 6.4 & 5.1 & 17.0 & 10.6 & 21.3 & 100 \\
\hline \multirow[t]{2}{*}{1996} & Number of cases & 4 & 19 & 21 & 41 & 22 & 29 & 29 & 28 & 33 & 29 & 38 & 37 & 330 \\
\hline & $\%$ & 1.2 & 5.8 & 6.4 & 12.4 & 6.6 & 8.8 & 8.8 & 8.4 & 10.0 & 8.8 & 11.6 & 11.2 & 100 \\
\hline 1997 & Number of cases & 6 & 23 & 17 & 28 & 24 & 33 & 29 & 139 & 58 & $?$ & $?$ & $?$ & $?$ \\
\hline
\end{tabular}


borne route of infection transmission among population is very active. This route of transmission is constantly (chronically) active in the territories with high morbidity rates. As a matter of fact, on that unfavorable epidemic background in Republic Dagestan in summer time of 1997 occurred a "sharp" waterborne epidemic, which caused 120 cases of typhoid fever. As an epidemic consequence, in that republic in $\mathrm{Au}-$ gust 1997 the biggest number of typhoid fever cases (138) was registered.

Taking into account very bad social-economic state of the population in RF in present time, it may be expected in the nearest years, that the activity of the waterborne route in the spread of typhoid fever will be greatly intensified as a direct result of money shortage for the capital construction and maintenance of the water supply and sewage disposal structure and pipe-nets in more or less satisfactory sanitary state.

\section{Seasonal distribution of paratyphoid fevers A, B, C}

Different from typhoid fever, paratyphoid fevers A,B,C in the recent years (1996-1997) were already registered not all years round - in some months the diseases were absent. In 1996 there were no cases of paratyphoid fevers in May and September, in 1997 in January. These data show rather clear, that paratyphoid fevers in RF are more and more losing their epidemic prospective and that this new epidemiological feature greatly and principally differs from typhoid fever. Nevertheless, similar with typhoid fever, most of cases of paratyphoid fevers A,B,C were also registered in the second half of the year (in 199622 out of 37 cases).

Females and males are among the typhoid fever patients. As compared with females, males contract typhoid fever in RF considerably more often. In 1996 among 330 sick persons there were only 115 females and 215 males (ratio 1:1.9). Among urban population (201 cases) had typhoid fever there were 70 females and 131 males (the same ratio 1:1.9), and among rural population (129 cases) - 45 females and 84 males (ratio 1:1.9). Notable prevalence of males among patients with typhoid fever not only among urban, but among rural population as well (almost two fold difference), reflects their increased social mobility, from one side, and lower level of sanitary rules observation, from another side.

\section{Chronic typhoid and paratyphoid carries}

After sickness with typhoid and paratyphoid fevers some part of convalescent (about 5-10\%) develops a state of so called chronic typhoid and paratyphoid carriership. These carriers, being practically healthy people, nevertheless during many tens of years and sometimes all life long continue to excrete $S$. typhi and S.paratyphi A,B.C with faeces and urine, pollute environment, including water and foodstuffs, and represent by themselves a direct epidemic threat for people around them. Effective methods for treatment of the carriership state still are not available and as a result these chronic carriers create a very powerful resevoir of infection, which very successfully secures persistence (survival) of the infectious agents ( $S$. typhi and S.paratyphi A,B.C) in nature and provides deep epidemic rooting of these infections on the global level (there are no countries in the world without cases of typhoid fever).

Number of chronic typhoid and paratyphoid carriers in RF is annually supplemented with new cases. In 1991, 78 new carriers were detected and registered, in 1992-93, in 1993-52, in 1994-47, in 1995-32, in 1996-37 and in 1997 (nine months) - 23 chronic carriers more.

Summary of statistical information concerning typhoid and paratyphoid carriers in RF is not available. Any way, taking into account the available data on the subject in Moscow it is possible, perhaps, to get some idea about carriership distribution in RF on the whole.

In Moscow in 1996 altogether 165 chronic typhoid carriers were registered, including 36 males and 129 females (ratio 1:3.6), 66 chronic paratyphoid B carriers, including 6 males and 60 females (ratio 1:10). Attention should be paid to a quite opposite ratio of male and females compared with typhoid fever pa-

Table 9. Seasonal distribution of paratyphoid fevers A,B,C in the Russian Federation in 1996-1997 (number of cases)

\begin{tabular}{ccccccccccccccc}
\hline & I & II & III & IV & V & VI & VII & VIII & IX & X & XI & XII & Total \\
\hline 1996 & 2 & 4 & 4 & 2 & 0 & 3 & 3 & 7 & 0 & 5 & 3 & 4 & 37 \\
1997 & 0 & 3 & 1 & 3 & 1 & 3 & 21 & 7 & 3 & $?$ & $?$ & $?$ & $?$ \\
\hline
\end{tabular}


tients. Besides, in Moscow in 19965 paratyphoid A carriers ( 3 males and 2 females) were also registered. If we sum together these data, concerning all carriers in Moscow (236 chronic carriers) and extrapolate them to the whole population of the Russian Federation (x 16.5) it would be obvious, that its population is harboring at least 4 thousands typhoid and paratyphoid carriers. But even this figure has to be at least doubled (8000) while the incidence levels of the disease in Moscow were always much lower than in the rest of territories in RF. Besides, it should be taken into consideration that some great movement of population into RF has been observed in the recent years, including active migration of people from southern territories of the former Union, where typhoid fever was constantly epidemically distributed and the level of chronic carriership was very high among the population. A very huge reservoir of chronic typhoid and paratyphoid carriership in RF is an important indicator of a very deep rooting of typhoid fever in this country for nowadays and very long future.

\section{Infection agent}

In accordance with Kauffman-White scheme (antigenic formula of salmonellae) typhoid fever agent Salmonella typhi - on composition of its somatic antigen belongs to the group $\mathrm{D}$, contains somatic antigens 9.12 and Vi-antigen-one of O-antigen's component. H-antigen (d) is available only in the first phase. Identification of the agent is very simple - strains of $S$. typhi, isolated in various territories, are typical concerning their cultural, biochemical and antigenic properties. The most effective laboratory method for diagnosis of typhoid fever (paratyphoid fevers $A, B, C$ ) remains an investigation of blood for a blood culture at the very beginning (first week) of the disease (person with fever during 5 days are obligatory investigated).

\section{Imported typhoid fever}

Some rather abrupt rise of import of typhoid fever into RF has been observed in the recent years. As a matter of fact an intensive import of the infection into Moscow is being realized by the RF citizens contracting typhoid fever abroad in neighborhood and remote countries, and also by foreign people, arriving to RF. Trend to increase of typhoid fever import is now very typical for the whole territory of RF and reflects abrupt strengthening of migration processes in the population inside RF, at the international level inside
UI'S(Union Independent States) and at the global level as well.

In Moscow in 1996 typhoid fever cases were imported from India, Nepal, Egypt (2 cases), Sri Lanka, Turkey and also from Aserbaidjan and Tajikistan, where typhoid fever is hyperendemic. In 1997 continued an intensive import of the infection from Aserbaidjan - 13 Aserbaidjan people fell sick with typhoid fever in the wholesale trade market "Moscow, Lusniki". They were closely interconnected between themselves in shoe trade business and belonged to one community. Import of typhoid fever took place also from Afghanistan, Bangladesh, Angola, India and again from Tajikistan, where epidemic situation with typhoid fever utmostly changed for the worse the disease has got hyperepidemic spread: in 1996 more than 17,000 cases were registered ( on WHO estimation occured not less than 50-60,000 cases) and the epidemic continues to develop in 1997.

Penetration of new and new numerous sources of the typhoid fever infection into RF will most probably have as a final epidemic result so called critical mass of these sources of the infection, which will cause in its turn at first active distribution of the disease via contact and foodborne routes and then by waterborne route - the most dangerous form of the epidemic process. At present time this trend has already taken place in RF and in the nearest future, no doubt, will get further active development.

\section{Phage type of S.typhi}

Intensive import of the typhoid fever infection particularly into Moscow has changed usual composition of phage types of the agent in the city. In 19931995 phage types $\mathrm{A}, \mathrm{E}_{\mathrm{l}}, \mathrm{B}_{2}$, were predominant; in 1997 phage type 28 (which was found very rare before) predominants, new phage types $\mathrm{F} 4$ and 45 occurred, and phage type $E_{1}$, which is very widely spread in Tajikistan maintained its distribution. A change of $S$. typhi phage types circulating in Moscow, which reflects unfavorable influence of some very active import of the infection on the typhoid fever epidemic process on the whole in RF, is an indicator of future undesirable complications of the epidemic process in the Russian Federation.

\section{Vaccination}

On the background of obvious deterioration of the epidemic situation in RF vaccination against typhoid fever is recommended: 
- to all foodhandlers and tradesman, including those who are working at wholesale and usual markets;

- to adult population from 18 to 50 years living in areas of high endemicity, where maintenance of good sanitation is difficult or impossible;

- to adult population travelling abroad to developing countries, where they would be subject to the danger to contract typhoid fever (endemic countries). 